\title{
Short-term nutrient pulses enhance growth and photosynthesis of the coral reef macroalga Sargassum baccularia
}

\author{
Britta Schaffelke ${ }^{1,2, *}$, David W. Klumpp ${ }^{1}$ \\ ${ }^{1}$ Australian Institute of Marine Science, PMB 3, Townsville MC, Queensland 4810, Australia \\ ${ }^{2}$ CRC Reef Research Centre, James Cook University, Townsville, Queensland 4811, Australia
}

\begin{abstract}
Due to their proximity to the mainland, nearshore reefs of the Great Barrier Reef (GBR), Australia, are directly subjected to land run-off. It is assumed that enhanced nutrient inputs to coastal waters are likely to lead to enhanced growth of primary producers. We simulated the effect of enhanced nutrient inputs on the growth and productivity of Sargassum baccularia (Mertens) C. Agardh, a large fucoid seaweed with a very high abundance on a number of nearshore reefs in the GBR. Nutrients were added as short-term pulses ( $24 \mathrm{~h}$ or $1 \mathrm{~h}$ duration) of ammonium and phosphate in addition to the natural background nutrients. Pulses of $8 \mu \mathrm{mol}$ ammonium and $1 \mu \mathrm{mol}$ phosphate, or higher, were taken up rapidly and significantly increased the tissue nutrient content in $S$. baccularia shoots. These nutrient stores were used to sustain enhanced growth and net-photosynthesis rates for about $1 \mathrm{wk}$. The strongest growth enhancement was obtained when ammonium and phosphate were applied together. The magnitude of the growth response was strongly dependent on the initial levels of tissue nutrients. In general, S. baccularia was highly responsive, underlining the nutrient limitation of this species at the field site. Nutrients are imported into the coastal zone of the GBR mainly by rain and riverine input, predominantly during the austral summer wet season. This is also the main growth period with the highest nutrient demand of the large Sargassum species. Our data suggest that an enhanced nutrient input during this season will significantly increase the productivity of these algae.
\end{abstract}

KEY WORDS: Nutrient pulses - Sargassum - Growth enhancement · Photosynthesis · Coral reef

\section{INTRODUCTION}

The overgrowth of coral reefs by macroalgae has been reported in several case studies from Hawaii, Florida, and the Caribbean during the past 2 decades (Smith et al. 1981, Lapointe 1989, Hughes 1994). An increase in nutrient inputs has been regarded as one of the major causes of this problem (Cuet et al. 1988, Lapointe et al. 1997). Nutrient inputs may have natural sources such as upwelling, rain and land run-off. In coastal areas, however, an increase in nutrient inputs can be caused by the downstream effect of agricultural land-use or by sewage discharge (Smith et al. 1981, Pastorok \& Bilyard 1985, Lapointe \& O'Connell 1989,

•E-mail: b.schaffelke@aims.gov.au
Szmant \& Forrester 1996). Other triggers for a distinct community shift from corals to macroalgae are the overfishing of herbivorous fish, as well as catastrophic events such as tropical cyclones or fatal diseases of grazers (Done 1992, Hughes 1994).

On nearshore reefs of the Great Barrier Reef, Australia (GBR), large brown algae, especially of the genera Cystoseira, Hormophysa, Sargassum, and Turbinaria, occur in high abundances, in addition to the typical coral reef turf algae community (Morrissey 1980, McCook et al. 1997, Schaffelke \& Klumpp 1997a). It is not known whether macroalgal abundance on GBR nearshore reefs has increased over the last decades, mainly because long-term datasets are lacking (discussed in McCook \& Price 1997).

Water column chlorophyll concentrations have been suggested as being the best indicators for long-term 
changes in available nutrients (e.g. Brodie et al. 1997); however, an increase in chlorophyll levels in GBR waters over the past centuries is still disputed (Bell 1991, 1992, Bell \& Elmetri 1995, Brodie et al. 1997). Due to their proximity to the mainland, nearshore reefs of the GBR are more directly subjected to land run-off than midshelf and outer reefs. A further increase in nutrients, which may result from this run-off in coastal waters is likely to lead to enhanced growth of primary producers. The use of agricultural fertiliser has significantly increased since the 1950s (Pulsford 1996) and increases in nutrient loads in rivers draining into the GBR lagoon have been estimated (Moss et al. 1992, Brodie 1997). However, the water column nutrient concentrations in the coastal zone are still relatively low (Furnas et al. 1995). One of the ways to advance our knowledge on responses to nutrient changes is to conduct controlled experiments.

Schaffelke \& Klumpp (1998) have shown by nutrient enhancement in continuous flow cultures that the growth of a very abundant Sargassum species was both nitrogen- and phosphorus-limited at 3 inshore reefs of the GBR and that growth was promoted by low level nutrient enhancements. The promotion of growth and productivity by nutrient enrichment has been shown for a number of tropical macroalgae (Nelson 1985, Lapointe 1987, 1989). In coral reef systems phosphorus (P) limitation may be more severe than nitrogen (N) limitation (Smith 1984) and in some cases addition of $\mathrm{P}$ alone has stimulated algal productivity (Lapointe 1985, 1987, 1989, Lapointe et al. 1987).

The experimental addition of nutrients in short-term pulses has long been used as a convenient study system (Lapointe 1985, 1995, Littler et al. 1991, Delgado \& Lapointe 1994). It has also been recognised that rapid short-term nutrient uptake rates and subsequent nutrient storage may be beneficial for macroalgae living in habitats where episodic nutrient supply is likely (Probyn \& Chapman 1982, Rosenberg et al. 1984, Fujita 1985, Fujita et al. 1989).

Nutrients are mainly imported into GBR waters through rain and riverine input (Furnas et al. 1995), which predominantly occur during the wet season in austral summer. This season is also the main growth period of the large Sargassum species (Martin-Smith 1993, Vuki \& Price 1994, Schaffelke \& Klumpp 1997a). Hence, the rain-driven, episodic nutrient inputs may be a main nutrient source to sustain the growth of these large seaweeds. If, as a result of human activity, nutrient import into the GBR increased, this would occur predominantly in a pulse-like fashion during the wet season. These pulses may be highly effective in promoting the growth of the abundant Sargassum species, because the nutrient demand of these algae is at a maximum during summer (Schaffelke \& Klumpp
1998). Since the reproductive period of most GBR Sargassum species is also in late summer, a nutrientenhanced productivity during the wet season may also lead to a higher reproductive output.

Sargassum baccularia (Mertens) C. Agardh is a large fucoid seaweed that is found throughout the coastal zone of the GBR and that has a very high abundance on a number of nearshore reefs (Schaffelke \& Klumpp 1997a). The objectives of the present study are to show whether the growth and photosynthesis of this species are promoted by short-term nutrient enhancements. Different concentrations, duration and frequencies of nutrient pulses are tested to assess the conditions for a maximum growth/productivity response.

\section{MATERIALS AND METHODS}

Collection of algae. Specimens of Sargassum baccularia were collected on the reef flat/developing lagoon of the fringing coral reef in Little Cannon Bay, Great Palm Island, a nearshore continental island in the central GBR $\left(146^{\circ} 35^{\prime} \mathrm{E}, 18^{\circ} 41^{\prime} \mathrm{S}\right)$. For a detailed description of this site, refer to Schaffelke \& Klumpp (1997a). Young, basal shoots of 4 to $8 \mathrm{~cm}$ length, which emerge from the holdfast tissue of $S$. baccularia thalli, were cut from entire thalli. Until used in experiments, the shoots were kept in a tank with flowing ambient seawater on board the research vessel. For later use in aquarium experiments, shoots were kept in flowing seawater in the outdoor aquarium facility of the Australian Institute of Marine Science (AIMS). For aquarium experiments it was necessary to control epiphytes on $S$. baccularia shoots. Shoots were pre-treated according to the following protocol: (1) discard shoots with visible macro-epiphytes, (2) wipe shoots with soft paper tissue, (3) wash in filtered $(0.45 \mu \mathrm{m})$ seawater. The shoots were left to recover for at least $48 \mathrm{~h}$ in flowing, filtered $(0.45 \mu \mathrm{m})$ seawater before they were subjected to experimental conditions.

Pulse treatments of $24 \mathrm{~h}$ duration. Pilot experiments in the aquarium: Two experimental runs with different nutrient pulse concentrations were carried out (Table 1, Expts a and b). Shoots were incubated for $24 \mathrm{~h}$ in 2 I clear plastic bottles (Nalgene) filled with $0.5 \mu \mathrm{m}$ filtered ambient seawater. Eight bottles were used for the nutrient pulse treatments, the water was fertilised to $5 / 0.5$ or $10 / 1$. ( $\mu \mathrm{M}$ ammonium/ $/ \mathrm{M}$ phosphate), respectively, with reagent-grade ammoniumchloride and sodium-dihydrogenphosphate. Water in the 8 control bottles was unfertilised. Water samples were taken from each control and treatment bottle for analyses of ammonia and phosphate concentrations according to Koroleff (1983a, b) Each of the 16 bottles contained 6 shoots, resulting in a fresh weight (FW) of 
3 to $5 \mathrm{~g}$ per bottle. The water was exchanged every $3 \mathrm{~h}$ to avoid significant depletion of the nutrient concentration. Nutrient measurements ensured that after $3 \mathrm{~h}$ the algae had taken up less than $30 \%$ of the initially added nutrients. After $24 \mathrm{~h}$, the shoots were blotted dry with tissue, weighed (FW), numbered with tape tags, and immediately returned to filtered seawater. One shoot per bottle was frozen $\left(-18^{\circ} \mathrm{C}\right)$ for analyses of tissue nutrients (see below). The treatment/control bottles were regarded as experimental units, resulting in $n=8$ replicates, each with 5 subsample shoots. After the pulse treatment, the shoots were kept in filtered natural seawater (flow rate $0.51 \mathrm{~min}^{-1}$ ) in a shallow tray $(2.0 \times 0.5 \times 0.1 \mathrm{~m})$ in the A.IMS aquarium system at ambient water temperature and photoperiod. The light intensity was reduced with shadecloth to values similar to those at the field site. After $4 \mathrm{wk}$, the FW of all shoots was determined to calculate specific growth rates. The 5 subsample shoots of each replicate bottle were pooled and frozen for analyses of tissue nutrients.

Field experiments: The experimental procedure was the same as described before, except that lengthspecific growth rates were calculated (length of shoots measured to the nearest mm using a calliper). Fourteen experimental runs with different pulse concentrations were conducted between August 1995 and October 1996 (Table 1, Expts c to f). The 5 subsample shoots from each experimental unit were individually numbered and fixed with rubber bands to plastic pegs embedded in a concrete block. This resulted in 8 concrete blocks, each with 5 control and 5 treatment shoots, which were then returned to the Sargassum zone at Great Palm Island. About 4 to 6 wh later, the concrete blocks were recovered, and the shoots measured and sampled for tissue nutrients.

Time series after pulse treatments: To assess the response of Sargassum baccularia shoots over time after a pulse treatment, growth and tissue nutrients of shoots were regularly monitored over a $5 \mathrm{wk}$ period in an aquarium experiment. The pulse treatment protocol was the same as described before, with the modifica- tion that each of 30 replicate shoots per treatment or control was treated independently in a $500 \mathrm{ml}$ jar. The pulse concentrations were $5 / 0.5,10 / 1$, and $20 / 2(\mu \mathrm{M}$ ammonium $/ \mu \mathrm{M}$ phosphate), plus untreated control plants (Table 1, Expt g). After the pulses, shoots were kept in flowing filtered seawater, as before. Growth of 10 designated shoots per treatment was monitored approximately every week by determination of FW. After the pulse treatments, and on each growth measurement occasion, 5 randomly selected shoots per treatment were sampled for analyses of tissue nutrients. At the end of the experiment, the shoots designated for growth measurements were pooled in pairs for tissue nutrient samples. The growth rates of this experiment were presented as integrated growth after $5 \mathrm{wk}$ and as specific growth rates over the time course.

Photosynthesis and respiration after pulse treatments: Photosynthesis and respiration of Sargassum baccularia shoots after a $24 \mathrm{~h}$ nutrient pulse were measured with a 4-chamber data-logging respirometer equipped with oxygen electrodes. An inbuilt pump exchanged the water in the measurement chambers every $15 \mathrm{~min}$. Full technical details on the respirometer are given in Klumpp et al. (1987). The pulse treatment was carried out as described in the above time course experiment, with a nutrient concentration of $8 \mu \mathrm{M}$ ammonium $/ 1 \mu \mathrm{M}$ phosphate, plus unfertilised control plants $(n=30)$. After the pulse, shoots were kept in a large basin $(1.2 \times 0.55 \times 0.2 \mathrm{~m})$ in filtered, flowing seawater (flow rate $0.5 \mathrm{l} \mathrm{min}^{-1}$ ) in a temperature-controlled room at a water temperature of $26^{\circ} \mathrm{C}$. Halogen lamps supplied a light intensity of $300 \mu \mathrm{mol}$ photons $\mathrm{m}^{-2} \mathrm{~s}^{-1}$ (measured at the chamber level), an irradiance saturating the photosynthesis of Sargassum spp. (Klumpp et al. in press). The respirometer chambers were immersed in the same basin. On Days 1 to 5 and 7 after the pulse, 10 randomly selected shoots from each treatment and control were measured. Photosynthesis was measured for $1 \mathrm{~h} 20 \mathrm{~min}$, and, after this, respiration was measured in the dark for the same time span. Hence, from immediately after the pulse until the

Table 1 Summary of experiments with pulse treatments of $24 \mathrm{~h}$ duration. Concentrations of pulse treatments are given in $\mu \mathrm{M}$ ammonium $/ \mu \mathrm{M}$ phosphate, $\mathrm{Co}=$ unfertilised control. Duration of experiments in weeks, $\mathrm{n}=$ replicate number for growth/tissue nutrients

\begin{tabular}{|lcclcc|}
\hline Description & Expt & Duration & Pulse concentration & n & Expt runs \\
\hline Pilot, aquarium & $\mathrm{a}$ & 4 & Co, $5 / 0.5$ & $8 / 8$ & 1 \\
Field & $\mathrm{b}$ & 4 & Co, $10 / 1$ & $8 / 8$ & 1 \\
& $\mathrm{C}$ & $4-6$ & Co, $8 / 1$ & $8 / 8$ & 8 \\
& $\mathrm{~d}$ & 4 & $\mathrm{Co}, 20 / 2$ & $8 / 8$ & 2 \\
Time course, aquarium & $\mathrm{e}$ & 4 & Co, $40 / 4$ & $8 / 8$ & 2 \\
& $\mathrm{f}$ & 6 & $\mathrm{Co}, 50 / 5$ & $10 / 5$ & 1 \\
\hline
\end{tabular}


end of the experiment, all treatment and control shoots experienced tinis $1 \mathrm{~h} 20 \mathrm{~min}$ light/dark cycle. Directly after the productivity measurements, the FW of the shoots was determined as described before. The oxygen evolution/consumption rates of the single shoots were related to dry weight (DW) using a FW/DW conversion factor determined at the end of the experiment Additionally, the specific growth rates of 10 designated shoots from each treatment and control were obtained by determining $\mathrm{FW}$ on 6 occasions during the $14 \mathrm{~d}$ after the pulse treatment.

Pulse treatments of $\mathbf{1} \mathrm{h}$ duration. Pulses at different frequencies: The protocol for the administration of the $1 \mathrm{~h}$ nutrient pulses was the same as that described for the time course after a $24 \mathrm{~h}$ pulse. The growth response of Sargassum baccularia shoots was measured by determining $\mathrm{FW}$ at the start of the experiments and after 4 wk. For each treatment 20 replicate shoots were used. The pulse concentrations were $3 / 0.3$ and 10/1 ( $\mu \mathrm{M}$ ammonium $/ \mu \mathrm{M}$ phosphate), plus unfertilised controls. In separate experiments, the $1 \mathrm{~h}$ pulse treatments were repeated with different frequencies: every $2 \mathrm{~d}$, once per week, or once per fortnight.

$N, P$, or $N+P$ enrichment: To distinguish between the effects of ammonium and phosphorus, both nutrients were added either alone or in combination. Following the above described $1 \mathrm{~h}$ pulse protocol, the pulses were repeated once per week for $4 \mathrm{wk}$ and the concentrations used were $0 / 2,20 / 0$, or $20 / 2(\mu \mathrm{M}$ ammonium $/ \mu \mathrm{M}$ phosphate), plus unfertilised controls.

Nutrient uptake during $1 \mathrm{~h}$ pulses: The nutrient uptake of Sargassum baccularia shoots was quantified in batch mode uptake experiments. Shoots of about $1 \mathrm{~g}$ FW were each incubated for $1 \mathrm{~h}$ in $0.5 \mathrm{l}$ of seawater containing different concentrations of ammonium or phosphate, with the respective other nutrient added at a saturating concentration $(10 \mu \mathrm{M}$ ammonium or $1 \mu \mathrm{M}$ phosphate). Water samples were taken in triplicate at the start of the experiment and after $1 \mathrm{~h}$ and were analysed for ammonium or phosphate, depending on which was being studied. In pilot experiments, a time course of ammonium uptake during the first hour was established, with measurements taken every $15 \mathrm{~min}$. This time course indicated linear uptake during the first hour (data not shown). For the estimation of the uptake kinetics, end-point measurements after $1 \mathrm{~h}$ were regarded as a reliable measure for uptake under conditions such as in the pulse treatments. The kinetic parameters $K_{\mathrm{s}}$ and $V_{\max }$ of the Michaelis-Menten hyperbolic equation and the respective confidence limits were calculated by a weighted linear regression technique (Wilkinson 1961).

Tissue nutrient analyses. Sargassum baccularia shoots were dried at $60^{\circ} \mathrm{C}$ for $24 \mathrm{~h}$, ground with mortar and pestle into a fine powder and stored at $-18^{\circ} \mathrm{C}$ until analysed. Total carbon and nitrogen were analysed with an ANTEK C/N analyser. For analysis of total phosphorus, ground tissue was combusted for $1 \mathrm{~h}$ at $450^{\circ} \mathrm{C}$ and extracted with purified water for $12 \mathrm{~h}$ at $4^{\circ} \mathrm{C}$, the extract was then filtered and analysed for total phosphorus according to Koroleff (1983c). The analyses of tissue nutrients was routinely carried out with material sampled after each pulse treatment and at the end of the respective experiments.

Data analyses. All data were analysed with the statistical package SuperAnova 1.11 (Abacus concepts Inc. 1989-90). Data were checked for homogeneity of variances with Cochran's test and, if necessary, log- or arcsine-transformed. Error estimates represent 95\% confidence limits, unless otherwise stated. The $24 \mathrm{~h}$ and $1 \mathrm{~h}$ pulse experiments were analysed with 1 -way ANOVAs, with treatment versus control as the factor and the growth responses at the end of the experiment as the dependent variables. To ensure a balanced design, even if subsample shoots were lost, averages of subsample shoots were taken as dependent variables in the $24 \mathrm{~h}$ pulse pilot and field experiments. For figures summarising the results of several experiments of the same type, the growth responses from each experiment were presented as percent growth enhancement relative to the respective controls. These relative values also enabled the comparison of the $24 \mathrm{~h}$ pulse experiments with different incubation times between 4 and $6 \mathrm{wk}$. The different units, length- and FW-specific growth rates, are directly comparable in Sargassum baccularia (Schaffelke \& Klumpp 1997a). The time course experiment was analysed with single 1 -way ANOVAs for each measurement day, with treatment versus control as the factor and the specific growth rates, tissue nitrogen, or tissue phosphorus contents as the dependent variables. The photosynthesis experiment was similarly analysed: the dependent variables in this case were net-photosynthesis, dark respiration, or specific growth rates. The $1 \mathrm{~h}$ pulse experiment with the addition of $\mathrm{N}, \mathrm{P}$ or $\mathrm{N}+\mathrm{P}$ was analysed with a 3-way ANOVA, with the factors being ' $N$ ' and ' $P$ ' (each in 2 levels, presence or absence) and 'tissue nutrients' ( 2 levels, high or low), and the specific growth rate as the dependent variable. In case of significant ANOVAs that involved more than 2 treatment levels, i.e. the time course experiment, differences between the treatments were tested by applying the Tukey Kramer comparison of means at the 1 or $5 \%$ significance level. The relationship between the concentrations of nitrogen or phosphorus in the tissue after a $24 \mathrm{~h}$ pulse and the respective pulse concentrations was described by a linear function, fitted to the data by least square regression. A $t$-test was applied to test if the slope of the regression line was significantly different from zero. 


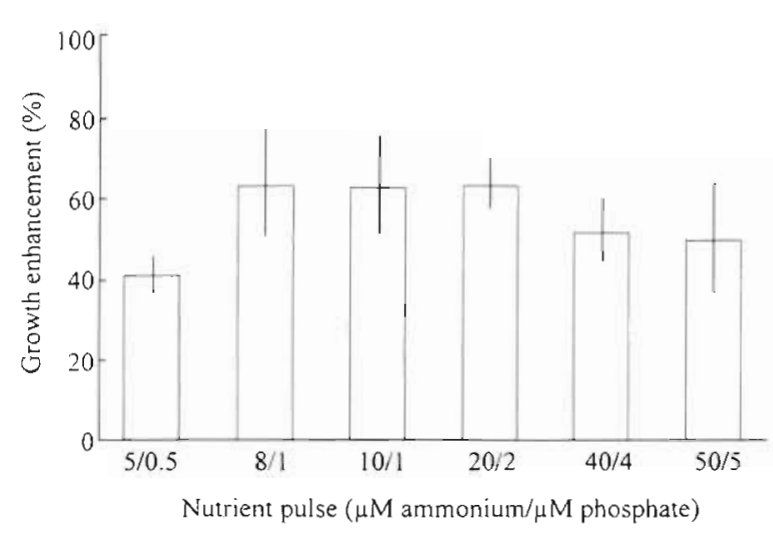

Fig. 1. Sargassum baccularia. Growth enhancement of shoots after single 24 h nutrient pulses in field and aquarium experiments. Bars represent the means of different experimental runs with $95 \%$ confidence intervals $(5 / 0.5=$ Expts a and $g$. $8 / 1=$ Expt $c_{1}, 10 / 1=$ Expts b and $g, 20 / 2=$ Expts $d$ and $g$ $40 / 4=$ Expt e, $50 / 5=$ Expt $\mathrm{f}$, experimental details in Table 1). Growth enhancements are calculated relative to the respective untreated control shoots

\section{RESULTS}

\section{Nutrient pulses of $24 \mathrm{~h}$ duration in field and aquarium experiments}

All 24 h nutrient pulses, in the field as well as in the aquarium experiments, resulted in a growth enhancement of Sargassum baccularia plants. Compared to the respective control plants in unfertilised seawater, the fertilised thalli grew significantly more after the $24 \mathrm{~h}$ pulse treatments with nutrient concentrations ranging from $5 / 0.5$ to $50 / 5(\mu \mathrm{M}$ ammonium/ $\mu \mathrm{M}$ phosphate) (Fig. 1). These pulse experiments were carried out during almost every month from August 1995 to October 1996. In every season, the pulse treatments significantly enhanced growth of S. baccularia thalli. The responses relative to the respective controls did not show distinct seasonal differences. Therefore, a detailed presentation of the results of the single experiments was omitted and instead the responses of S. baccularia shoots in the $24 \mathrm{~h}$ pulse experiments with different nutrient concentrations were compiled (Fig. 1). The 1-way ANOVAs for each separate experiment revealed significant differences between the growth of control and pulse-treated plants at the $5 \%$ level (complete ANOVA tables not shown).

The pulse treatment generally resulted in a significant increase in tissue $\mathrm{N}$ and $\mathrm{P}$ stores immediately after the pulse. The tissue $N$ and $P$ concentrations increased linearly with increasing ammonium and phosphate concentration in the nutrient pulse (Fig. 2). The slopes of the obtained regression equations were significantly different from 0 ( $t$-test, $p<0.01$, for both $N$ and $P$ ) and the regression coefficients $\mathrm{r}^{2}$ were 0.92 for tissue $\mathrm{N}$ and 0.94 for tissue $\mathrm{P}$.

\section{Time course after 24 h nutrient pulses}

To study the physiological changes after a single 24 h nutrient pulse in more detail, Sargassum baccularia thalli were measured weekly in an aquarium experiment. Directly after the pulses of 3 different concentrations, a significant increase in tissue nutrients was measured in thalli from the 3 treatments compared to control plants (Fig. 3a, b). One-way ANOVAs were calculated for each measurement day and for each of the response variables, tissue $N$, tissue $\mathrm{P}$, and growth rate (Table 2). Directly after the $24 \mathrm{~h}$ pulse, the tissue $\mathrm{N}$ levels in plants from the 3 pulse treatments were significantly higher than in the controls and also significantly different from each other. Pulses with higher ammonium concentrations resulted in higher tissue $\mathrm{N}$ content (Table 2). In Weeks 1 and 2 after the pulse, only the tissue $\mathrm{N}$ of the plants in the highest pulse treatment was still significantly higher than in the other treatments. From Week 3.5 onwards, no differ-
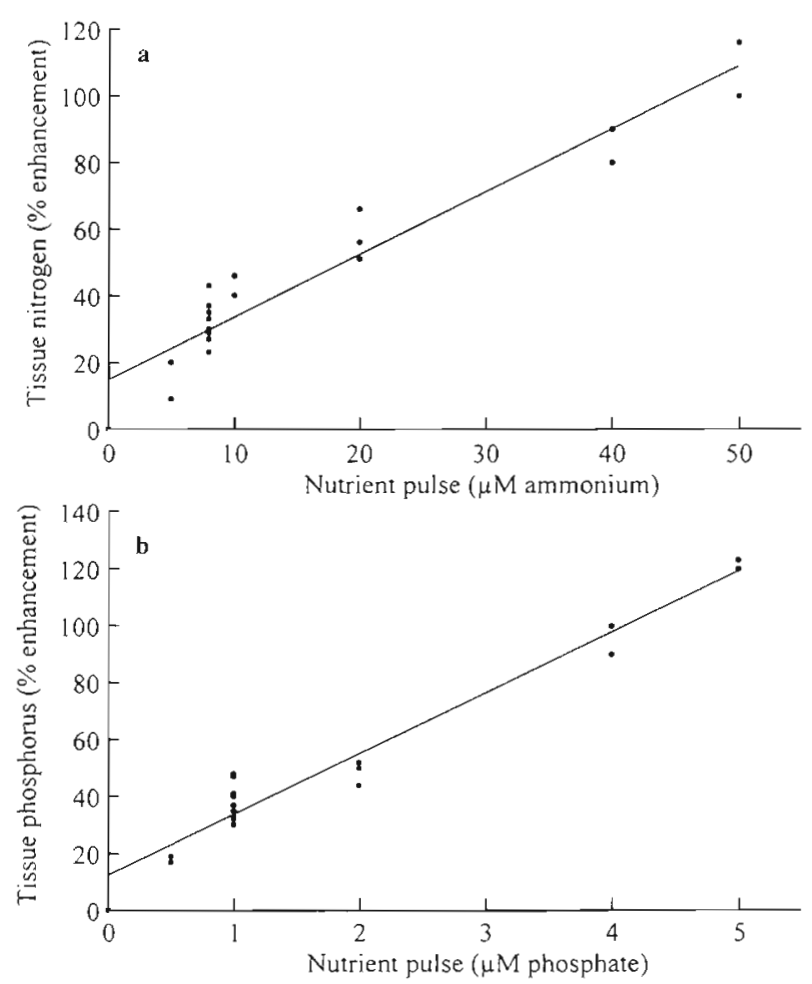

Fig. 2. Sargassum baccularia. (a) Nitrogen and (b) phosphorus content in tissue after single $24 \mathrm{~h}$ nutrient pulses. Each data point represents the mean value of the tissue nutrient level, calculated as enhancement relative to the respective control shoots of one experimental run (experimental details in Table 1). Line represents the least square regression 

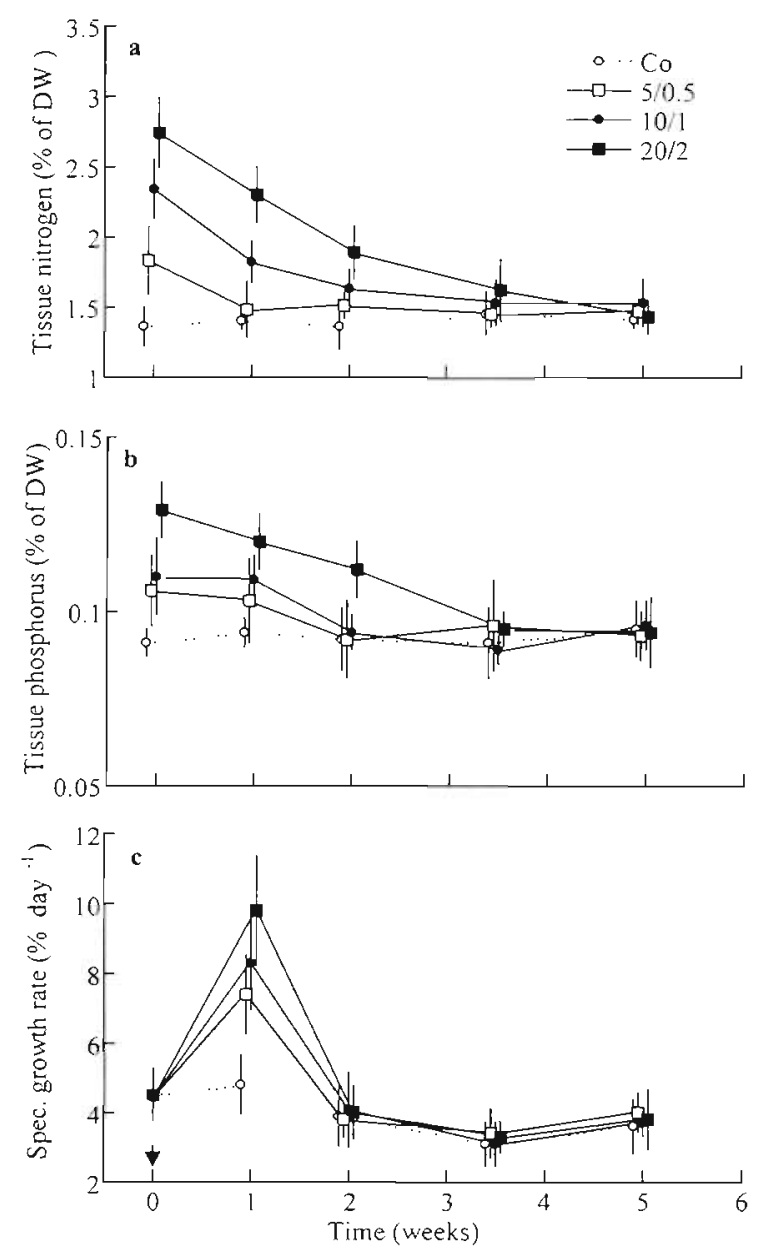

Fig. 3. Sargassum baccularia. Time course of tissue (a) nitrogen and (b) phosphorus levels, and (c) specific growth rates of shoots after single $24 \mathrm{~h}$ nutrient pulses (arrow). Data points are means of $n=5$ samples for tissue nutrients and $n=10$ for growth rates with $95 \%$ confidence intervals. Co: Control shoots; pulse treatments: 5/0.5, 10/1, and 20/2 $\mu \mathrm{M}$ ammonium/ $\mu \mathrm{M}$ phosphate

ence was found between the tissue $N$ levels of the plants from all treatments (Table 2). Analyses of the tissue $P$ levels revealed the same general patterns as for the tissue $\mathrm{N}$ (Table 2). The growth rates of pulsetreated plants were significantly higher than those of the control plants for only $1 \mathrm{wk}$ after the pulse (Fig. 3c, Table 2). The growth rates of the control plants remained constant for the duration of the experiment.

\section{Photosynthesis and respiration after $24 \mathrm{~h}$ nutrient pulses}

The effect of a $24 \mathrm{~h}$ nutrient pulse was not only measurable as a growth response, but also as an immediate photosynthesis response. Directly after an 8/1 pulse ( $\mu \mathrm{M}$ ammonium $/ \mu \mathrm{M}$ phosphate) the net photosynthesis is enhanced by $30 \%$ compared to control plants (Fig. 4 a). This enhancement was significant from Days 1 to 5 after the pulse (1-way ANOVA for single days, $p<0.01$ ). At Day 7 the net photosynthesis was not significantly different from that of control plants (1-way ANOVA: $F_{1,18}=$ 1.61, $p=0.22$ ). The respiration rates were analysed in the same way and the 1 -way ANOVAs for each measurement day showed significantly higher respiration rates of treatment plants only on Day 3 (1-way ANOVA: $F_{1,18}=$ $6.53, p=0.02$ ). Rates on the other days were not significantly different between treatments (1-way ANOVA for single days, $p>0.05$ ).

The parallel growth measurements offered further detail on the growth response after a 24 h nutrient pulse. For $6 \mathrm{~d}$ after the pulse, the nutrient-treated plants displayed significantly enhanced growth rates with a peak on Day 4 (Fig. 4b, 1-way ANOVAs for single days, $\mathrm{p}<0.01$ ). After $10 \mathrm{~d}$ the growth of treatment and control plants was not significantly different (1-way ANOVAs for Days 10 and 14, p > 0.05).

\section{Nutrient pulses of $1 \mathrm{~h}$ duration at different irequencies}

The nutrient pulses of only 1 h duration also resulted in an enhancement of growth of Sargassum baccularia,

Table 2. Sargassum baccularia. Time course of specific growth rates and tissue nutrients of shoots after single $24 \mathrm{~h}$ nutrient pulses applied at the start of week $0(5,10,20$ represent the respective pulse concentrations $5 / 0.5,10 / 1,20 / 2 \mu \mathrm{M}$ ammonium/ $\mu \mathrm{M} \mathrm{phos}$ phate) or untreated control shoots (Co). F- and p-values for 1-way ANOVAs are given for data of each measuring week. Conclusions are results of Tukey Kramer comparisons of means (<: significantly smaller at $5 \%$ error level; ns: no significant difference)

\begin{tabular}{|c|c|c|c|c|c|c|c|c|c|}
\hline \multirow[t]{2}{*}{ Week } & \multicolumn{3}{|c|}{ Tissue nitrogen } & \multicolumn{3}{|c|}{ Tissue phosphorus } & \multicolumn{3}{|c|}{ Specific growth rate } \\
\hline & $F_{3,16}$ & $\mathrm{p}$ & Conclusion & $F_{3,16}$ & $\mathrm{p}$ & Conclusion & $F_{3,36}$ & $\mathrm{p}$ & Conclusion \\
\hline 0 & 41.8 & $<0.01$ & Co $<5<10<20$ & 16.7 & $<0.05$ & $C_{0}<5,10<20$ & - & - & - \\
\hline 1 & 28.5 & $<0.01$ & $\mathrm{Co}, 5<10<20$ & 8.2 & $<0.05$ & $\mathrm{Co}, 5<20$ & 19.2 & $<0.01$ & $\mathrm{Co}<5,10,20$ \\
\hline 2 & 8.5 & $<0.05$ & Co, $5<20$ & 6.9 & $<0.05$ & $\mathrm{Co}, 5,10<20$ & 1.2 & $>0.05$ & ns \\
\hline 3.5 & 1.2 & $>0.05$ & n.s & 0.6 & $>0.05$ & ns & 0.7 & $>0.05$ & ns \\
\hline 5 & 1.0 & $>0.05$ & ns & 2.0 & $>0.05$ & ns & 0.9 & $>0.05$ & ns \\
\hline
\end{tabular}




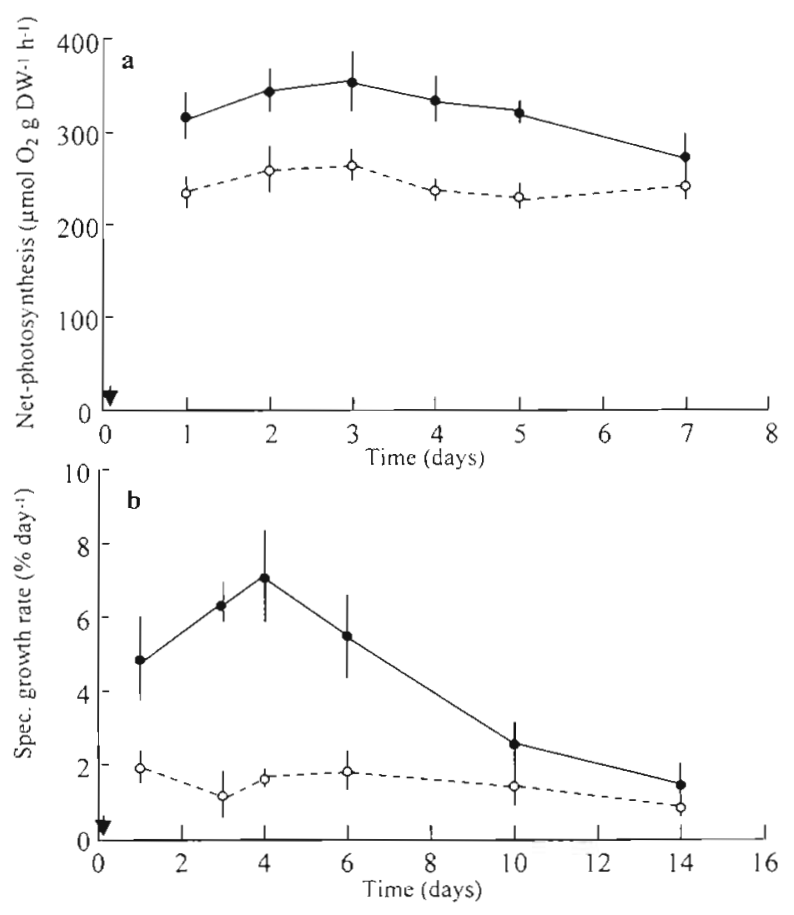

Fig. 4. Sargassum baccularia. Time course of (a) net-photosynthesis and (b) specific growth rates of shoots after a single $24 \mathrm{~h}$ nutrient pulse (arrows) with the concentration $8 \mu \mathrm{M}$ ammonium $/ 1 \mu \mathrm{M}$ phosphate (solid line) or of untreated control shoots (dashed line). Data are means $(n=10)$ with $95 \%$ confidence intervals

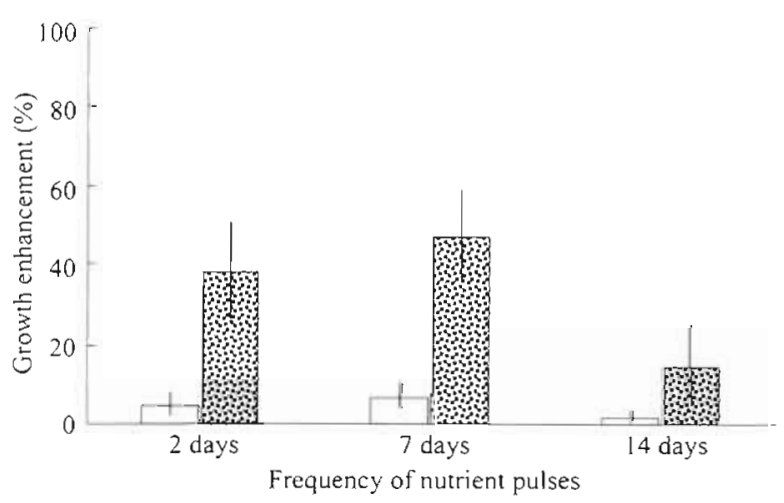

Fig. 5. Sargassum baccularia. Growth enhancement of shoots after 1 h nutrient pulses given at different frequencies and concentrations: $3 / 0.3$ ( $\mu \mathrm{M}$ ammonium $/ \mu \mathrm{M}$ phosphate; white bars) or $10 / 1$ (stippled bars). Growth enhancement is calculated relative to the respective untreated control shoots. Bars represent means of $\mathrm{n}=20$ shoots with $95 \%$ confidence intervals

depending on the nutrient concentrations and the frequencies of the pulse application. The less-concentrated nutrient pulses ( $3 \mu \mathrm{M}$ ammonium/0.3 $\mu \mathrm{M}$ phosphate) did not result in a significant increase in growth compared to control plants in the 3 experimental fre-
Table 3. Sargassum baccularia. Three-way ANOVA comparing the effects of $1 \mathrm{~h}$ nutrient pulse additions of $20 \mu \mathrm{M}$ ammonium and $2 \mu \mathrm{M}$ phosphate ( $\mathrm{N}, \mathrm{P}$, each in 2 levels, present/absent) and of tissue nutrients (Tissue, in 2 levels, high/low) on the growth of shoots after 4 wk

\begin{tabular}{|lrrr|}
\hline Source & df & F-value & p-value \\
\hline $\mathrm{N}$ & 1 & 54.71 & 0.0001 \\
$\mathrm{P}$ & 1 & 12.50 & 0.0006 \\
Tissue & 1 & 659.69 & 0.0001 \\
$\mathrm{~N} \times \mathrm{P}$ & 1 & 3.37 & 0.0992 \\
$\mathrm{~N} \times$ Tissue & 1 & 10.41 & 0.0016 \\
$\mathrm{P} \times$ Tissue & 1 & 4.34 & 0.0394 \\
$\mathrm{~N} \times \mathrm{P} \times$ Tissue & 1 & 2.19 & 0.1418 \\
Error & 112 & & \\
\hline
\end{tabular}

quencies (Fig. 5; 1-way ANOVAs for each frequency, $\mathrm{p}>0.05)$. The more-concentrated pulses $(10 \mu \mathrm{M}$ ammonium $/ 1 \mu \mathrm{M}$ phosphate) enhanced the growth of S. baccularia shoots if the treatment was given every second day or once per week (Fig. 5; 1-way ANOVAs, $\mathrm{p}<0.01$ ). In contrast, a pulse every $2 \mathrm{wk}$ did not result in a significant growth enhancement (Fig. 5; 1-way ANOVA: $F_{2,57}=2.07, \mathrm{p}=0.14$ ).

\section{$N, P$, or $N+P$ enrichment}

In $1 \mathrm{~h}$ pulse treatment experiments, we tested the effect of either $\mathrm{N}$ or $\mathrm{P}$ or both $\mathrm{N}$ and $\mathrm{P}$ enrichment on the growth of Sargassum baccularia thalli. The 2 experimental runs had plant material with different initial tissue nutrient contents. One run had shoots with relatively high nutrient levels, $1.4( \pm 0.2) \% \mathrm{~N}$ of DW and $0.1( \pm 0.03) \%$ P of DW, and the other run had relatively low levels, $0.9( \pm 0.1) \% \mathrm{~N}$ of DW and 0.06 $( \pm 0.02) \% \mathrm{P}$ of DW. The 3-way ANOVA revealed that both the nutrients added by the pulse treatments and the initial tissue nutrient content had significant effects on the growth of the treated shoots (Table 3). The addition of $\mathrm{N}$ or of P significantly increased growth, but the interaction between the nutrients $(\mathrm{N} \times \mathrm{P})$ was not significant (Table 3). The interactions of both $\mathrm{N}$ and $\mathrm{P}$ with the initial tissue nutrients $(\mathrm{N} \times$ Tissue, $\mathrm{P} \times$ Tissue) were significant, indicating that the response was dependent on the initial tissue nutrient status. The interaction of the simultaneously added nutrients and the tissue nutrient status $(\mathrm{N} \times \mathrm{P} \times$ Tissue) was not significant (Table 3). For the 2 experimental runs separately, the magnitude of the responses is shown in Fig. 6. When both tissue $N$ and $P$ were relatively high, the overall growth response was small. With plant material that had a relatively low internal nutrient status, the overall response to a nutrient enrichment was 


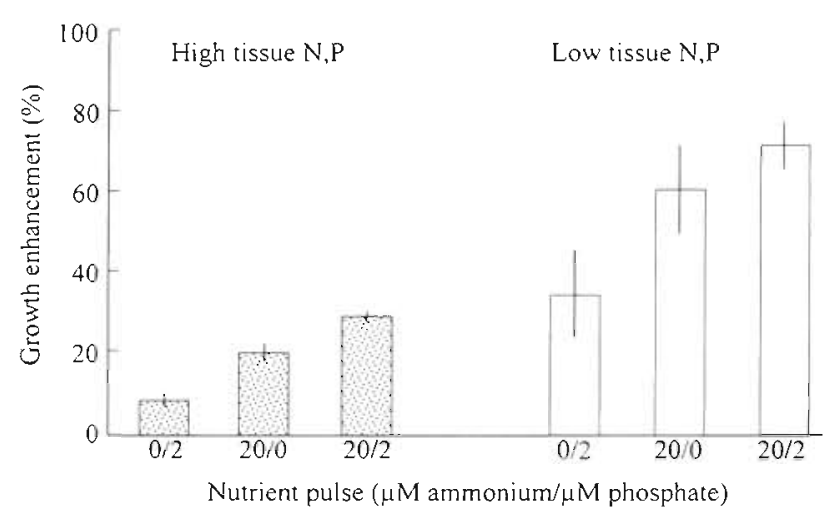

Fig. 6. Sargassum baccularia. Growth enhancement of shoots after 1 h nutrient pulses. Stippled bars: shoots with high initial tissue nutrients; white bars: shoots with low initial tissue nutrients. Growth enhancement is calculated relative to the respective untreated control shoots. Bars represent means of $n=20$ shoots with $95 \%$ confidence intervals

much stronger. The response to an addition of both $\mathrm{N}$ and $P$ was in both runs larger than the response to only 1 element (Fig. 6).

\section{Nutrient uptake during $1 \mathrm{~h}$ pulses}

In general, the $1 \mathrm{~h}$ nutrient pulses resulted in a 10 to $20 \%$ increase in tissue $\mathrm{N}$ and $\mathrm{P}$, compared to untreated control plants (data not shown). The significant increase in tissue $\mathrm{N}$ stores was reflected in high ammonium uptake rates at ammonium concentrations such as those used in the nutrient pulse experiments (Fig. 7). The ammonium uptake rates were determined in $1 \mathrm{~h}$ batch mode experiments under the same experimental conditions as the above $1 \mathrm{~h}$ pulse experiments. The rate of ammonium uptake was a saturable function of the ammonium concentration and followed the Michaelis-Menten relationship (Fig. 7). Uptake appeared to be saturated in substrate concentrations above $30 \mu \mathrm{M}$ ammonium (Fig. 7). The kinetic parameters were estimated as $15.6 \mu \mathrm{M}$ ammonium for the half-saturation $\left(K_{\mathrm{s}}\right)$ concentration and as $111.1 \mu \mathrm{M}$ ammonium $\mathrm{g}^{-1} \mathrm{DW} \mathrm{h}^{-1}$ for the maximal uptake rate $\left(V_{\text {max }}\right)$.

It was not possible to establish such a relationship between phosphate uptake and substrate phosphate concentration. A time course revealed that in initial concentrations of less than $1 \mu \mathrm{M}$ phosphate no net uptake was measurable after $1 \mathrm{~h}$, and the phosphate concentrations even increased. At higher substrate concentrations, first an increase in phosphate was measured, followed by decreasing concentrations after 30 to $45 \mathrm{~min}$. Because of this ambiguity, results of phosphate uptake were not considered further

\section{DISCUSSION}

Inshore coral reefs of the GBR are vulnerable to anthropogenic disturbances due to their proximity to the predominantly diffuse sources of various inputs from the mainland, such as siltation, freshwater, nutrients, heavy metals, and pesticides. Most reports about reef degradation around the world concern fringing coral reefs, and, although the identified causes are quite different between the cases, in general the reefs appear to sustain the growth of macroalgae rather than of hermatypic corals (reviewed in Done 1992). Eutrophication has been identified as one of the main threats to coral reefs throughout the world (Pastorok \& Bilyard 1985, Lapointe et al. 1997).

The present study simulated in field and aquaria experiments the effects of enhanced nutrient inputs on the growth and productivity of the tropical seaweed Sargassum baccularia. Because $S$ baccularia is very abundant on nearshore coral reefs of the GBR (Schaffelke \& Klumpp 1997a), it colonises habitats that already sustain large macroalgal stands. Exposure of plants to simulated nutrient pulses with durations as short as $1 \mathrm{~h}$ resulted in an up to $60 \%$ enhancement of the growth and photosynthesis of $S$. baccularia.

Water column nutrients in the GBR lagoon are low and often at the detection limit (Furnas et al. 1995). The average water column nutrient concentrations at our study site were about $0.3 \mu \mathrm{M}$ dissolved inorganic nitrogen (DIN) and $0.02 \mu \mathrm{M}$ phosphate (Schaffelke \& Klumpp 1998). These values are below the threshold limits (1 $\mu \mathrm{M}$ DIN, $0.1 \mu \mathrm{M}$ phosphate) suggested by Lapointe et al. (1993, 1997) and Bell (1992) above

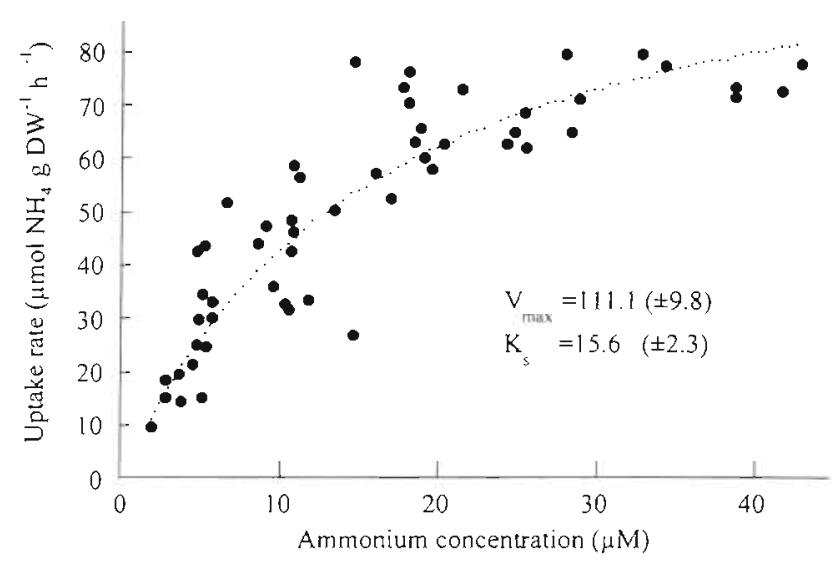

Fig. 7. Sargassum baccularia. Short-term ammonium uptake rates vs ammonium concentration in batch mode experiments. Each data point represents the uptake rate of a single shoot. Dotted line: Michaelis-Menten curve fit derived by substitution of the kinetic parameters calculated by weighted linear regression 
which macroalgal blooms have been observed on coral reefs. However, Hatcher \& Hatcher (1981), Crossland \& Barnes (1983), and Staunton Smith \& Johnson (1995) reported nutrient levels in the water column on reefs that exceeded these threshold limits. In the GBR region high nutrient concentrations and river plumes of short duration may occur during the summer monsoonal wet season, when the import of nutrients predominantly occurs via stochastic discharge events (Steven et al. 1996, Mitchell \& Furnas 1997). Nutrient concentrations in the flood plumes reach values of 0.26 to $16.1 \mu \mathrm{M}$ DIN and 0.03 to $0.54 \mu \mathrm{M}$ phosphate, depending on distance from the coast and weather conditions (Steven et al. 1996). Therefore, it is especially important to consider the effect of a pulsed nutrient supply when making predictions on possible responses of GBR nearshore reef communities to enhanced nutrients.

Previously, we have reported that Sargassum baccularia was both $\mathrm{N}$ - and P-limited at the investigated nearshore reef sites, and that the growth was enhanced by the continuous supply of additional nutrients in concentrations lower than in the present study (Schaffelke \& Klumpp 1998). S. baccularia is most receptive to additional nutrients during the summer wet season, because this is the time of the seasonal growth maximum of this species, and also because during this period both the nutrient demand and the nutrient limitation are most pronounced (Schaffelke \& Klumpp 1997a, 1998).

In the present study, considerable luxury stores of $\mathrm{N}$ and $\mathrm{P}$ were accumulated in the experimental thalli of Sargassum baccularia, depending on the concentrations of the nutrient pulses, and these sustained enhanced photosynthesis and growth for about a week. Lobban \& Harrison (1994) calculated the nutrient storage capacity from the quotient of maximal and minimal tissue nutrient levels. The $\mathrm{N}$ and $\mathrm{P}$ storage capacity of $S$. baccularia is about 4 , which is slightly higher than values available for a range of temperate and tropical macroalgae (calculated from data compiled in Lobban \& Harrison 1994). However, much higher values are reported for the chlorophyte Chaetomorpha linum, which formed a macroalgal bloom in an estuary in southwest Australia (Lavery \& McComb 1991). The capacity to utilise stored nutrients to sustain growth over a prolonged period of time when nutrient availability is low may be a competitive advantage of macroalgae over phytoplankton and opportunistic epiphytes.

Phytoplankton is generally viewed as the first recipient of any available nutrients in the water column (Brodie et al. 1997). The competition for nutrients between the primary producers on coral reefs, i.e. macroalgae, phytoplankton, microphytobenthos, and symbiotic algae, may determine the extent of a production stimulation of Sargassum baccularia caused by nutrients in situ. Plankton responds quickly to shortterm nutrient inputs and is regarded as a suitable tracer for nutrient pulses of natural or anthropogenic origin (Furnas et al. 1995, Brodie et al. 1997). We suggest that large Fucales may serve as indicators for enhanced nutrients if surveyed over a long time frame, since both adults and juvenile plants respond positively to increases in available nutrients.

The few in situ nutrient enhancement experiments on coral reefs have shown ambiguous results for the enhancement of macroalgal productivity or growth (Kinsey \& Domm 1974, Hatcher \& Larkum 1983, Larkum \& Koop 1997). Several problems are associated with in situ nutrient enhancement experiments, such as high or variable background nutrient levels or the possibility that the added nutrients are lost by tidal flushing or taken up by reef biota other than macroalgae (Hatcher \& Larkum 1983, A. Steven pers, comm.). This problem has been circumvented by pulse-treating algae only in shipboard tanks (Lapointe et al. 1987, Littler et al. 1991, Delgado \& Lapointe 1994, Lapointe 1995). Similar to Lapointe $(1985,1987,1989)$, we administered only the nutrient pulse treatments on board ship and afterwards the algae were kept in situ to develop the growth response.

In the present study, field and aquaria-cultured plants essentially responded similarly to the same nutrient treatments. The efficacy of a nutrient pulse depended mainly on its concentration and frequency. The minimum nutrient concentrations for a pulse to have an effect were $5 \mu \mathrm{M}$ ammonium and $0.5 \mu \mathrm{M}$ phosphate. The strongest growth enhancing effect was induced by pulses with a concentration of at least $8 \mu \mathrm{M}$ ammonium and $1 \mu \mathrm{M}$ phosphate. The effect of both the $1 \mathrm{~h}$ and the $24 \mathrm{~h}$ pulses lasted for about $1 \mathrm{wk}$, then the accumulated tissue nutrients were exhausted. The duration of a pulse appears to be of lesser importance, because $24 \mathrm{~h}$ and $1 \mathrm{~h}$ pulses of appropriate concentrations gave essentially the same growth response (cf. Figs. 1, 5 \& 6); however, the 24 h pulses resulted in higher tissue nutrient levels. Also, the initial tissue nutrient status had a strong effect on the expression of the pulse effect. If the internal $N$ and $P$ reserves were already above the critical tissue nutrient level (according to Hanisak 1979; levels for Sargassum baccularia in Schaffelke \& Klumpp 1998), the growth enhancement was comparably weak. Very pronounced responses were achieved with depleted internal stores. For most experiments we used freshly collected field material which had tissue nutrients just below the critical $N$ and $P$ levels, which is consistent with levels observed in material sampled at the field site over a 15 mo period (Schaffelke \& Klumpp 1998). 
Nitrogen-limited growth of coral reef algae has been reported in several publications (e.g. Hatcher \& Larkum 1983, Larned \& Stimson 1996). Phosphorus limitation was shown to be more important than nitrogen limitation in tropical waters of the Atlantic and Indian Ocean (Lapointe 1985, 1989). However, this response was dependent on the geology of the habitat (Littler et al. 1991), the season (Lapointe 1987, Delgado \& Lapointe 1994) or the species (Lapointe et al. 1987). Schaffelke \& Klumpp $(1997 b, 1998)$ showed that growth of adult field Sargassum baccularia is both nitrogen- and phosphorus-limited and that the growth of early life history stages in culture is enhanced by $\mathrm{N}$ and $P$ addition. In the present study both $N$ and $P$ pulses were effective in enhancing growth of this species; however, the maximal response was achieved when both elements were supplied together.

Acknowledgements. We are grateful to Eric Bunn of the Palm Island Ranger Service for the permission to work on the reef in Little Cannon Bay. B.S. was funded by a research fellowship of the Deutsche Forschungsgemeinschaft (Scha 676/1-1). This is publication no. 923 from the Australian Institute of Marine Science.

\section{LITERATURE CITED}

Bell PRF (1991) Status of eutrophication in the Great Barrier Reef lagoon. Mar Pollut Bull 23:89-93

Bell PRF (1992) Eutrophication and coral reefs - some examples in the Great Barrier Reef lagoon. Wat Res 26:553-568

Bell PRF, Elmetri I (1995) Ecological indicators of large-scale eutrophication in the Great Barrier Reef lagoon. Ambio 24: $208-215$

Brodie JE (1997) The water quality status of the Great Barnier Reef World Heritage Area. In: Wachenfeld D, Oliver J, Davis K (eds) State of the Great Barrier Reef World Heritage Area Workshop. Workshop Series No. 23, Great Barrier Reef Marine Park Authority, Townsville, p 69-97

Brodie JE, Furnas MJ, Steven ADL, Trott LA, Pantus F, Wright $M$ (1997) Monitoring chlorophyll in the Great Barrier Reef lagoon: trends and variability. Proc 8 th Coral Reef Symp 1: $797-802$

Crossland J, Barnes DJ (1983) Dissolved nutrients and organic particulates in water flowing over coral reefs at Lizard Island. Aust J Mar Freshwat Res 34:835-844

Cuet P, Naim O, Faure G, Conan JY (1988) Nutrient-rich groundwater impact on benthic communities of La Saline fringing reef (Reunion Island, Indian Ocean): preliminary results. Proc 6th Int Coral Reef Symp 1:207-212

Delgado O, Lapointe BE (1994) Nutrient-limited productivity of calcareous versus fleshy macroalgae in a eutrophic, carbonate-nch tropical marine environment. Coral Reefs 13: $151-159$

Done TJ (1992) Phase shifts in coral communities and their ecological significance. Hydrobiologia 247:121-132

Fujita RM (1985) The role of nitrogen status in regulating transient ammonium uptake and nitrogen storage by macroalgae. J Exp Nar Biol Ecol 99:283-301

Fujita RM, Wheeler PA, Edwards RL (1989) Assessment of macroalgal nutrient limitation in a seasonal upwelling region. Mar Ecol Prog Ser 53:293-303

Furnas MJ, Mitchell AW, Skuza M (1995) Nitrogen and phosphorus budget for the Central Great Barrier Reef Shelf. Research Publication No. 36, Great Barrier Reef Marne Park Authonty, Townsville, p 1-194

Hanisak MD (1979) Nitrogen limitation of Codium fragile ssp. tomentordes as determined by tissue analysis. Mar Biol 50: 333-337

Hatcher AI, Hatcher BG (1981) Seasonal and spatial variation in dissolved inorganic nitrogen in One Tree Island lagoon. Proc 4th Int Coral Reef Sym 1:419-424

Hatcher BG, Larkum AWD (1983) An experimental analysis of factors controlling the standing crop of the epilithical algal community on a coral reef. J Exp Mar Biol Ecol 69:61-84

Hughes TP (1994) Catastrophes, phase-shifts and large scale degradation of a Caribbean coral reef. Science 265: $1547-1551$

Kinsey DW, Domm A (1974) Effects of fertilisation on a coral reef environment - primary production studies. Proc 2nd Int Coral Reef Symp 1:49-66

Klumpp DW, Done TJ, McKinnon AD, Robertson AI, Brunskill GJ (in press) Response of nearshore reefs to nutrient enhancement. Phase I: baseline information on nutrient concentrations, primary production and reef community structure. Research Publication. Great Barrier Reef Marine Park Authority, Townsville

Klumpp DW. McKinnon DA, Daniel PA (1987) Damselfish territories: zones of high productivity on coral reefs. Mar Ecol Prog Ser 40:41-51

Koroleff F (1983a) Determination of ammonia. In: Grasshoff K, Ehrhardt M, Kremling K (eds) Methods of seawater analyses. Verlag Chemie, Weinheim, p 150-157

Koroleff $F$ (1983b) Determination of dissolved inorganic phos. phate. In: Grasshoff $K$, Ehrhardt $M$, Kreming $K$ (eds) Methods of seawater analyses. Verlag Chemie, Weinheim, p $126-131$

Koroleff $F(1983 c)$ Determination of total phosphorus by acid persulphate oxidation. In: Grasshoff K, Ehrhardt M, Kremling $K$ (eds) Methods of seawater analyses. Verlag Chemie, Weinheim, p 134-136

Lapointe BE (1985) Strategies for pulsed nutrient supply to Gracilaria cultures in the Florida Keys: interactions between concentration and frequency of nutrient pulses. $J$ Exp Mar Biol. Ecol 93:211-222

Lapointe BE (1987) Phosphorus- and nitrogen-limited photosynthesis and growth of Gracilaria tikvahiae (Rhodophyceae in the Florida Keys: an experimental field study. Mar Biol 93:561-568

Lapointe BE (1989) Macroalgal production and nutrient relations in oligotrophic areas of Florida Bay. Bull Mar Sci 44: $312-323$

Lapointe BE (1995) A companson of nutrent-limited productivity in Sargassum natans from neritic vs. oceanic waters of the Western North Atlantic Ocean. Limnol Oceanogr 40: $625-633$

Lapointe BE, Littler MM, Littler DS (1987) A comparison of nutrient-limited productivity in macroalgae from a Caribbean barrier reef and from a mangrove ecosystem. Aquat Bot 28:243-255

Lapointe BE, Littler MM, Littler DS (1993) Modification of benthic community structure by natural eutrophication: The Belize Barrier Reef. Proc 7th Int Coral Reef Symp 1: $323-334$

Lapointe BE, Littler MM, Littler DS (1997) Macroalgal overgrowth of fringing coral reefs at Discovery Bay, Jamaica: Bottom-up versus top-down control. Proc 8th Int Coral Reef Symp 1:927-932 
Lapointe BE, O'Connell J (1989) Nutrient-enhanced growth of Cladophora prolifera in Harrington Sound, Bermuda: eutrophication of a confined phosphorus-limited marine ecosystem. Estuar Coast Shelf Sci 28:347-360

Larkum ADW, Koop K (1997) ENCORE, algal productivity and possible paradigm shifts. Proc 8 th Int Coral Reef Symp $1: 881-884$

Larned ST, Stimson J (1996) Nitrogen-limited growth in the coral reef chlorophyte Dictyosphaeria cavernosa, and the effect of exposure to sediment-derived nitrogen on growth. Mar Ecol Prog Ser 145:95-108

Lavery PS, McComb AJ (1991) The nutritional ecology of Chaetomorpha linum and Ulva rigida in Peel Inlet, Western Australia. Bot Mar 34:251-260

Littler MM, Littler DS, Titlyanov EA (1991) Comparisons of Nand P-limited productivity between high granitic islands versus low carbonate atolls in the Seychelles Archipelago: a test of the relative-dominance paradigm. Coral Reefs 10:199-209

Lobban CS, Harrison PJ (1994) Seaweed ecology and physiology. Cambridge University Press, New York

Martin-Smith KM (1993) The phenology of four species of Sargassum at Magnetic Island, Australia. Bot Mar 36: $327-334$

McCook LJ, Price IR (1997) Macroalgal distributions on the Great Barrier Reef: A review of patterns and causes. In: The Great Barrier Reef, science, use and management. A national conference: Proceedings, Vol 2. Great Barrier Reef Marine Park Authority, Townsville, p 37-46

McCook LJ, Price IR, Klumpp DW (1997) Macroalgae on the GBR: causes or consequences, indicators or models of reef degradation. Proc 8th Int Coral Reef Symp 2:1851-1856

Mitchell AW, Furnas MJ (1997) Terrestrial inputs of nutrients and suspended sediments to the GBR lagoon. In: The Great Barrier Reef, Science, use and management. A national conference: Proceedings, Vol 1. Great Barrier Reef Marine Park Authority, Townsville, p 59-71

Morrissey J (1980) Community structure and zonation of macroalgae and hermatypic corals on a fringing reef flat of Magnetic Island (Queensland, Australia). Aquat Bot 8: 91- 139

Moss AJ, Rayment GE, Reilly N, Best EK (1992) A preliminary assessment of sediment and nutrient exports from Queensland coastal catchments. Environment Technical Report No. 5. Queensland Department of Environment and Heritage, Brisbane

Nelson SG (1985) Immediate enhancement of photosynthesis by coral reef macrophytes in response to nutrient enrichment. Proc 5th Int Coral Reef Symp 5:65-70

Editorial responsibility: Otto Kinne (Editor),

Oldendorf/Luhe, Germany
Pastorok RA, Bilyard GB (1985) Effects of sewage pollution on coral-reef communities. Mar Ecol Prog Ser 21:175-189

Probyn TA, Chapman ARO (1982) Nitrogen uptake characteristics of Chordaria flagelliformis (Phaeophyta) in batch mode and continuous mode experiments. Mar Biol 71 $129-133$

Pulsford JS (1996) Historical nutrient usage in coastal Queensland river catchments adjacent to the Great Barrier Reef Marine Park. Research Publication No. 40, Great Barrier Reef Marine Park Authority, Townsville

Rosenberg G, Probyn TA, Mann KH (1984) Nutrient uptake and growth kinetics in brown seaweeds: response to continuous and single additions of ammonium. J Exp Mar Biol Ecol 80:125-146

Schaffelke B, Klumpp DW (1997a) Biomass and productivity of tropical macroalgae on three nearshore fringing reefs in the central Great Barrier Reef, Australia. Bot Mar 40: 373-383

Schaffelke B, Klumpp DW (1997b) Growth of germlings of the macroalga Sargassum baccularia (Phaeophyta) is stimulated by enhanced nutrients. Proc 8 th Int Coral Reef Symp 2:1839-1842

Schaffelke B, Klumpp DW (1998) Nutrient-limited growth of the coral reef macroalga Sargassum baccularia and experimental growth enhancement by nutrient addition in continuous flow culture. Mar Ecol Prog Ser 164:199-211

Smith SV (1984) Phosphorus versus nitrogen limitation in the marine environment. Limnol Oceanogr 29:1149-1160

Smith SV, Kimmerer WJ, Laws EA, Brock RE, Walsh TW (1981) Kaneohe Bay sewage diversion experiment: perspectives on ecosystem responses to nutritional perturbation. Pac Sci 35:84-92

Staunton Smith J, Johnson CR (1995) Nutrient inputs from seabirds and humans on a populated coral cay. Mar Ecol Prog Ser 124:189-200

Steven A, Devlin M, Brodie J, Baer M, Lourey M (1996) Spatial influence and composition of river plumes in the central Great Barrier Reef. In: Hunter HM, Eyles AG, Rayment GE (eds) Downstream effects of land use. Department of Natural Resources, Queensland, Australia, p 85-92

Szmant AM, Forrester A. (1996) Water column and sediment nitrogen and phosphorus distribution patterns in the Florida Keys, USA. Coral Reefs 15:21-41

Vuki VC, Price IR (1994) Seasonal changes in the Sargassum populations on a fringing coral reef, Magnetic Island, Great Barrier Reef region, Australia. Aquat Bot 48: $153-166$

Wilkinson GN (1961) Statistical estimations in enzyme kinetics. Biochem J 80:324-332

Submitted: March 18, 1998; Accepted: June 8, 1997

Proofs received from author(s): August 12, 1998 